\title{
TAP2 wt Allele
}

National Cancer Institute

\section{Source}

National Cancer Institute. TAP2 wt Allele. NCI Thesaurus. Code C52306.

Human TAP2 wild-type allele is located in the vicinity of $6 \mathrm{p} 21.3$ and is approximately $9 \mathrm{~kb}$ in length. This allele, which encodes antigen peptide transporter 1 protein, plays a role in the modulation of the conformation and the activity of major histocompatibiltiy complex class I proteins. Mutations in this gene are associated with bare lymphocyte syndrome and rheumatoid arthritis. 